\title{
Reassessing the dependence of capitalism on democracy - the case of Imperial Germany and the Weimar Republic
}

\author{
Gerhard Wegner \\ Faculty of Economics, Law, and Social Sciences, University of Erfurt, Erfurt, Germany \\ Corresponding author. Email: gerhard.wegner@uni-erfurt.de
}

(Received 2 July 2019; revised 29 November 2019; accepted 4 December 2019)

\begin{abstract}
The paper interrogates the argument put forward by Acemoglu and Robinson or North et al. that capitalism and democracy are supportive to each other. It analyzes the development of political and economic institutions in Germany before and after World War I. It is shown that the lack of democracy in Imperial Germany furthered a liberal economic order and gives reasons why the transition to full-scale parliamentarianism would have impaired the quality of economic institutions. This also explains why such a transition was not completed. The Weimar Republic established a modern democracy but was unable to secure the quality of economic institutions achieved before. Not only in Germany did the politicization of the economy impair the economic order. This empirical outcome helps to explain why Eucken and other liberals identified democracy as part of the economic problem during the interwar period. It also gives reasons to rethink the complex relationship between capitalism and democracy.
\end{abstract}

Keywords: Capitalist transformation; economic and political order; historical case study

\section{Introduction}

Recent approaches in institutional economics emphasize a positive link between capitalism and democracy. Thereby they revise earlier views suggested by Olson, Hayek and others who argue that political competition in democracy tends to undermine the market order because distributional coalitions are striving for rents. ${ }^{1}$ North et al. (2009) coin the term 'open access order' by which they mean that free access of all members in society rules both the market sphere and politics. Economically this implies that an open access order does not discriminate against citizens with respect to business activities, professions or trading. Broadly speaking open access orders confer equal economic rights to all citizens. In contrast to 'Limited Access Orders' no elite or 'dominant coalition' holds exclusive economic rights and thereby creates rents through market barriers. The institutional requirements which guarantee economic freedom to all individuals - the protection of property rights, the freedom of occupation, the freedom of movement, the freedom of contract, the freedom to found organizations, the freedom of establishment for firms - constitute a capitalist economic order. To make economic freedom an enforceable right, equality before the law is imperative, which thus becomes a necessary condition for capitalism in the sense defined above. In this view, capitalism depends on how governmental power is wielded rather than who governs. ${ }^{2}$ Hayek conducts such a thought experiment but eventually rejects the possibility of an authoritarian capitalism; finally he

\footnotetext{
${ }^{1}$ See Olson (1982) or Hayek $(1991,2005)$.

${ }^{2}$ See Hayek (2005: 132).

( ) Millennium Economics Ltd 2020. This is an Open Access article, distributed under the terms of the Creative Commons Attribution licence (http://creativecommons.org/licenses/by/4.0/), which permits unrestricted re-use, distribution, and reproduction in any medium, provided the original work is properly cited
} 
comes to the conclusion that democracy is at least 'an important guarantor' for individual liberty and the rule of law. ${ }^{3}$ North et al. (2009) offer compelling reasons that democracy will outperform any other order in this respect, particularly orders which limit access to political rule. Politically, an open access order gives all individuals a chance to take part in the competition for votes and to participate in political power. In contrast to a limited access order in which an elite group reigns, access to political power is principally open to everyone. Unlike proponents of constitutional economics, North et al. (2009) do not discuss the constitutional constraints that limit the power of the majority and prevents it from discriminating against the minority. ${ }^{4}$ But these constraints are certainly implicitly assumed. Democracy thus becomes equivalent to an open access order that exposes political power to competition and makes its duration ipso facto uncertain. Electoral winners cannot permanently seize political power, distinguishing the open access order from an autocracy or oligarchy; in principle, political power remains contestable by rivals. An 'illiberal democracy' is considered to be a contradiction in terms. Even though a winning coalition in a democracy could (and will) employ its power to grant economic advantages to its voters, the rule of law will channel such attempts, as North et al. reply to Olson. ${ }^{5}$ Briefly, the principle of competition dovetails democracy with a free market order. Once achieved, both orders will form a 'double balance' (North et al., 2009).

North et al. (2009) view advancements in the rule of law as the driving force for establishing an open access order and tiptoe around the question of whether democracy causes capitalism or vice versa. But their view is optimistic as regards the capability of an open access order to stabilize itself. In this perspective, it is inconceivable that it regresses into a limited access order; competition will continue to rule the economic as well as the political sphere. This appears to form the overlapping consensus of many scholars in this field and has inspired empirical tests. The so-called 'HayekFriedman-hypothesis' is the most prominent example (Lawson and Clark, 2010). It concedes the fact that non-democratic regimes which have achieved a high level of economic freedom are at least theoretically possible, even though this combination may be considered unlikely or unstable (see above); only in this case would low scores of political freedom coincide with high scores of economic freedom (ibid.). The Hayek-Friedman-hypothesis rules out the concomitance of democracy with low scores of economic freedom; no democracy, as Friedman states, has ever established a planned economy (Friedman, 1962). According to the Hayek-Friedman-hypothesis, the coinciding of political freedom and capitalism is the more likely combination, which is supported by empirical tests (Lawson and Clark, 2010).

Acemoglu and Robinson (2012), in turn, give causal priority to democracy when a free market order is to be established. Sketchy overviews of the development of modern capitalism since the industrial revolution in Britain are designed to support this view that the distribution of political power takes precedence over economic institutions. If elites hold exclusive political rights, the argument goes, it will create permanent economic rents for itself. Granting equal economic rights would engender economic dynamism in a way which is likely to change de-facto political power: as a result of equal economic rights entrepreneurship outside of the ruling elite would burgeon; newcomers would run businesses and challenge the economic position of the political power holders. A case in point, to which Acemoglu and Robinson repeatedly refer, is the role of the nobility in pre-industrial European countries. ${ }^{6}$ As their income rested on land tenure, they could not have had an interest in the emergence of the industrial sector. With hindsight the agricultural sector lost its economic relevance in terms of employment and production share, which, in turn, gave birth to an aspiring social class of the bourgeoisie. As long as the traditional nobility held political power, it was rational to resist capitalist economic institutions and the foreseeable creative destruction of one's own economic sector. Only in the countries where political power of the nobility was contained, Acemoglu and Robinson

\footnotetext{
${ }^{3}$ See Hayek (2005: 139).

${ }^{4}$ See Buchanan and Congleton (1998).

${ }^{5}$ For a discussion of Olson's arguments see North et al. (2009: 140-147); see also Buchanan and Congleton (1998); for an empirical investigation offering mixed results see Stroup (2008).

${ }^{6}$ See Acemoglu and Robinson (2012: 85) or Acemoglu et al. (2004: 43).
} 
claim, could capitalism develop. ${ }^{7}$ Therefore, democracy is considered a necessary condition for capitalism. But it would also be a sufficient condition since equal economic rights which contribute to entrepreneurship and ultimately to economic growth always correspond to the 'objective' interest of the majority.

As there are good theoretical reasons that democracy is complementary to capitalism, the empirical relationship between capitalism and the political order has proven to be complex. This holds true even for Britain: its Industrial Revolution was at an advanced stage when the Reform Act of 1832 widened the scope of parliamentary representation in society with a first, imperfect step. Even before World War I (WWI), the census suffrage excluded larger parts of society from political participation. ${ }^{8}$ By contrast, the encompassing transformation of society after the fall of communism in 1989 represents the first case in history to introduce democracy and capitalism simultaneously, but many of these transitions have achieved neither. The period after WWI, in turn, led to a wave of democratization all over Europe. However, a stable combination or a 'double balance' between democracy and a free market order often failed; 13 European countries which began as democracies ended as authoritarian regimes, among them Italy, Spain, Portugal, Poland, Germany, as well as Eastern and South-Eastern European states (besides Russia), leading to, among other things, dictatorship, fascism and national socialism. These economies were under political control, cartelized and far from free-market economies, even if they did not adopt a planned order like in Bolshevist Russia. The fact that both capitalism and democracy failed challenges the idea of a hierarchical order between politics and the economy (Acemoglu and Robinson), but also the idea of mutual reinforcement in the sense of a double balance (North et al.). The pre-war period provides a case that democracy need not be necessary for capitalism, whereas the interwar period contests that it is a sufficient condition.

The following is motivated by the fact that a general theory of the relationship between capitalism and democracy is not at hand, notwithstanding vast theoretical and empirical findings. ${ }^{9}$ Carefully selected case studies can make valuable contributions and are necessary to widen our understanding about the interplay between the political and the economic order. ${ }^{10}$ According to the arguments below, I review whether both democracy and capitalism are intrinsically self-stabilizing or even legitimate orders from the viewpoint of the majority. A well performing capitalist order can emerge in the absence of a fully-fledged democracy and prove to be stable, while a perfect parliamentary system can undermine capitalism in a way which leads to the self-destruction of both democracy and capitalism. The former was the case in Imperial Germany, the latter in the Weimar Republic. Even though many unique historical explanatory factors are relevant and are discussed by historians to this very day, some explanatory factors should be identifiable which extend the special case. The following is a search for these factors in order to modify and extend existing approaches.

The case of Germany before and after WWI is germane to current research in institutional economics for many reasons. ${ }^{11}$ During the 19th century the formerly agrarian economy developed into a center of capitalism within a few decades, whereby institutional change played an important role. Before WWI, Imperial Germany created a comprehensive institutional framework for a free market order without having a corresponding democracy. A detailed analysis demonstrates that this institutional framework was self-stabilizing even though the head of government was not elected by the citizenry or by parliament. I argue that the system of checks and balances within the rather exceptional federal order of Imperial Germany consisting of monarchies, Duchies and Grand Duchies prepared

\footnotetext{
${ }^{7}$ See Acemoglu and Robinson (2012: 222-231).

${ }^{8}$ However, see de Haan and Sturm (2003) who give evidence that for developing countries democracy may cause more economic freedom.

${ }^{9}$ For an overview of empirical studies concerning the possible causal relationship between democracy and prosperity, see Sunde (2006).

${ }^{10}$ For case studies concerning the development of civil liberties and democracy, see Congleton (2011: Part II). Case studies are also indispensable for historical indices to measure economic freedom; see Prados (2016).

${ }^{11}$ For an attempt to interpret political and economic history in Germany from the perspective of North et al. (2009) see Grimmer-Solem et al. (2019).
} 
the stage for the adjustment of economic institutions and ipso facto for strong and vigorous economic development. The long-lasting debate on a German Sonderweg (special path) has obscured the fact that WWI turned out to be the crucial watershed in the process of institutional change. The radical introduction of democracy combined with the elimination of traditional political institutions through the centralization of the German state after the abolishment of the sub-monarchies made the liberal order much more vulnerable than the pre-WWI order had ever done. This change removed the balance of power between political bodies and monopolized the legislative power of parliament. Democracy also meant politicization of the institutional requirements of the market order. The governments of the Weimar Republic were both unable and unwilling to re-establish the liberal pre-WWI economic order. This unwillingness was paralleled by anti-liberal policies of other European democracies on the international stage. Long-term economic stagnation and calamity followed which had disastrous effects as to the moderation of distributional conflicts, particularly when external shocks placed the political system under stress. In this respect, one could interpret democracy at that time as part of the problem. Allow me to substantiate these general points below.

In Section 2, I describe the political and economic constitution in Imperial Germany with emphasis on its interplay. Section 3 analyzes how the new political order of democracy in the Weimar State affected, and partly undermined, the capitalist order. ${ }^{12}$ Section 4 focuses on the international dimension and describes how the collapse of the international economic order aggravated the internal problems of the economic order in Germany. Section 5 concludes.

\section{The political and economic constitution of Imperial Germany}

\section{The political constitution}

A political constitution in the narrow sense means the whole set of political institutions which determine political decision-making. It encompasses the regime type of the state - e.g. monarchy, democracy, constitutional monarchy etc. -, the distribution of political power among political bodies - government, parliament, a Federal Council etc. - and among the national and the subnational levels. Constitutions define how its political bodies are assembled, typically by voting rights. They also define civil rights of the citizens and institutional arrangements to determine if and how these rights are enforceable. The degree and specific form of the separation of powers is a central element of any political constitution. Furthermore, a political constitution lays down the competences of the respective political bodies and procedures to change the political institutions, e.g. by altering the competences of political bodies or the distribution of political power. Formal institutions matter but informal norms and habits can affect formal institutions as well. For instance, the veto right of a political body may be constitutional but can become outdated as a result of changing informal political norms. A case in point is diminishing role of the House of Lords in Britain during the 19th century.

If we concentrate on the political and economic constitution of Germany before WWI, the North-German Federation founded in 1866 is a suitable starting point. It was the precursor to Imperial Germany, founded in 1871, and set the stage for the political and economic constitution thereafter. The North-German Federation was the first constitution in Europe to establish universal male suffrage. Its leading member state, Prussia, stuck to the class-voting system, which divided the citizenry into three classes according to their tax-payments. As a result, the vast majority (approximately $85 \%$ of the voters) were underrepresented in parliament but at least held some voting rights, which differed from other (census) voting rights systems of the time. In terms of the political spectrum, liberal parties dominated the parliaments in Prussia and the federal parliament in the early decades; later, the socialist party gained momentum in the Reichstag and became the leading faction in 1913.

Imperial Germany experienced a rather exceptional political order because it established a constitutional monarchy which itself consisted of other states, mostly constitutional monarchies, Duchies

\footnotetext{
${ }^{12}$ I use the term 'Weimar State' and 'Weimar Republic' interchangeably.
} 
and Grand-Duchies, but also three independent cities (Hamburg, Bremen and Lübeck). The formal constitution was a mixture of a constitution and a treaty among states which still held considerable competences of a nation state. As one consequence, the constitution did not contain a catalog of fundamental rights; these were settled in the constitutions of the member states. In many important states, above all in Prussia, they encompassed civil rights, such as the freedom of the press, the inviolability of the home, the freedom of assembly, the freedom of speech but also the freedom of teaching and research as an individual right for professors at universities. The head of government (chancellor) was not elected by parliament but appointed by the Emperor (Kaiser) who also appointed the ministers of the cabinet. Legislative proposals required the majority of both the parliament and the Federal Council whose members were sent by the governments of the member states. As a result, both chambers had a veto right.

The Emperor lacked the right to veto legislation, which was a crucial difference to other constitutional monarchies, e.g. the constitution of the Habsburg Empire, but also to Tsarist Russia after the establishment of the Duma. The formal right to dissolve parliament, of which he made use in a few cases, was constrained by the obligation of holding new elections immediately. Informally, the power of parliament kept growing throughout the era until WWI because agreement of the coalition on which the chancellor rested his power was crucial for law making; conversely, the informal power of the Federal Council had diminished. ${ }^{13}$ Legislative initiatives could be undertaken by government and parliament. Article 23 of the Constitution granted this right to parliament of which it made frequent use (the so-called initiative proposal). Hence, except for the right to elect the prime minister (Chancellor), parliament in Imperial Germany held all competences of a parliament in a democracy, including taxation. Parliamentary inquiries of government did not belong to its formal rights; informally, however, government had to justify its policies in order to avoid the rejection of proposals (Kroll, 2013: 15).

In an informative study, Anderson (2009) examines numerous facets of the electoral system in Imperial Germany, offering general insights into the process of incipient democratization. Though the political system was not a democracy, frequently cited claims of a negligible role of parliament are inappropriate. They fail to give account particularly for growing participation rates in elections, which eventually led to a turnout of approximately $80 \%$. If it is rational to vote at all, it would not be rational to participate in meaningless elections just as it would not be rational for parties to invest in campaigns (Anderson, 2009: 37-42). Even though conservatives, temporarily backed by the Emperor, made attempts to restore the ban against the erstwhile growing Socialist party, parliament fended off such proposals. At the turn of the century parliament represented a significant center of power which balanced the power of the government and the Emperor. Besides, the federal order contributed to the division of political power. Informally, critical print media served as a check on the government as well; several press campaigns successfully compelled members of the government to resign. ${ }^{14}$ In short, even though the formal process of full democracy lagged behind, informal rules pushed Imperial Germany more and more to a modern parliamentary system.

\section{The economic constitution}

By an economic constitution I understand the whole set of institutions which determine the scope and extent of economic autonomy of the citizenry - among them property rights, freedom of trade, freedom of establishment, inheritance laws, fiscal rules concerning taxation and public spending, the monetary constitution, and public regulation of private activities. ${ }^{15}$ Despite the lack of democracy in Imperial Germany, a process of liberalization of the economic institutions gained momentum. Unlike top-down liberalization of economic institutions at the beginning of the 19th century, which

\footnotetext{
${ }^{13}$ See Kroll (2013: 97-105).

${ }^{14}$ See Bösch (2009).

${ }^{15}$ For a detailed analysis, see Ambrosius (2005).
} 
overcame the late-absolutist economic order of mercantilism, liberal parties which represented the emerging bourgeoisie initiated these reforms (Blackbourn and Eley, 1980: 7-70). In the short period of the North-German Federation, all institutions of modern capitalism had been introduced or completed $^{16}$ : the state withdrew any pre-capitalist controls of the mining sector; joint stock companies were generally permitted which included the banking sector; reforms in the care for the poor (i.e. the abandonment of the 'home town principle') made workers' migration possible ${ }^{17}$; and the introduction of a universal commercial code further improved the legal foundations of capitalism. With these reforms the North-German Federation intended to assume economic leadership in the area of the Tariff Union (Zollverein), which had created a common market for the German middle states (but excluding Austria). As a result, the other middle states were exposed to competitive pressures to adjust their economic institutions as well. This included investments in the public sector, among them transportation, general education, vocational schools and universities. Competition of the states in the field of economic policy became prominent and characterized the economic order of Imperial Germany until its dissolution. The 'four economic freedoms' (freedom of trade, services, capital and labor) became instantaneously guaranteed as individually enforceable rights. Additionally, the country-of-origin principle with respect to regulations removed non-tariff trade barriers within the German territories (Ambrosius, 2005: 43). Thus, all institutional requirements for 'market preserving federalism' became established (Weingast, 1995).

Prior to the foundation of the Reich and even before the foundation of the North German Confederation, liberal ideas shaped the dawn of the new era after the restoration epoch of the 1840 s came to an end. The strong economic development until 1857, which was carried by high private investments, caused an increase of GDP per capita from 1855 to 1870 by 32\% (Boch, 2004: 34). Adam Smith's liberal ideas no longer proved to be an abstract promise, but a viable economic policy strategy for overcoming pauperism in the 1840s, which shaped the world view of Marx and Engels. In the 'Congress of German Political Economists', a mouthpiece was created for a decidedly liberal trade and economic policy, whereby the Congress also wanted to contribute to overcoming the 'poverty of the working classes'. The 'Verein für Socialpolitik' which was founded later placed a stronger emphasis on the 'social question', but also sought a compromise with economic liberalism. Especially in the founding years of Imperial Germany, a liberal mood prevailed, but this did not preclude state action. For example, the Prussian state prohibited entrepreneurs from paying wages in kind, which often invited fraud (ibid., 33). The parliamentarians of the North German Federation continued their liberalization efforts and even wanted to build up the North German Federation as a liberal model state', which put the South German states and Austria under pressure to follow suit. This also succeeded and finally the southern German states also pursued a more pronounced liberal economic policy. Within the extant political order, the representatives of liberalism and the bourgeoisie used all the opportunities available to them to realize their ideas of a liberal economic order.

The distribution of tax revenues corresponds to the liberal constitution of the state through a decentralized distribution of state revenues. The federal state absorbed approximately $40 \%$ of total tax revenues - consumption taxes, tariff revenues and revenues from public enterprises (from the railway among others) - and the states and municipalities received $20 \%$ and $40 \%$, respectively (Spoerer, 2004: 119); the total tax load accounted for $10 \%$ of the national income until 1913 (ibid.). Only states and municipalities levied income taxes, surtaxes on land and business taxes. This fiscal decentralization proved to be a business-friendly environment; recent research confirms the hypothesis of an increase in tax competition (ibid., 122; Hallerberg, 1996). Financial compensation or bail out-clauses among the states or among the Reich and the states did not exist; all levels of government were exclusively responsible for their own fiscal policy. A federal income tax was not introduced throughout the period until WWI, which limited the financial resources of the central government.

\footnotetext{
${ }^{16}$ A period of reforms in order to establish formal capitalist institutions started after 1808 in the wake of the Napoleonic Wars.

${ }^{17}$ For an informative study on immigration in Imperial Germany, see Grant (2005).
} 
Overall, economic institutions were highly favorable for entrepreneurship and private investment; its results entailed unprecedented growth of the economy as well as high technological dynamism, among them the emerging chemical and electrical industry. State expenditures of eventually $15 \%$ of the national income in 1913 and the concentration of public expenditures on public goods rather than redistribution suggest that many criteria of a free-market economy were met. In the labor-market, the free-market order limited the influence of unions. As compared to Britain, the power of German unions was more limited. Unions were allowed and, later on, could also negotiate wages. However, according to a judgment of the Supreme Court, wage agreements were not generally binding, which is why individual wage contracts dominated in the economic order. Entrepreneurs benefitted from this arrangement.

The classification of economic policy in Imperial Germany as generally liberal is likely to provoke alternative views on this subject, particularly from historians and the history of economic thought. A vast literature addresses the role of the state in Imperial Germany or makes the claim of a special type of 'organized capitalism', indicating that capitalist development resulted from state interventionism rather than from free markets. ${ }^{18}$ Depending on the author's ideological stance, this claimed role of the state is praised or criticized and sometimes even both. ${ }^{19}$ But, this literature largely overstates the organizational role of the state in this epoch. Above all, assessments of historians as to the role of state largely suffer from the fact that the term 'intervention' is too vague. The expression hardly differentiates between the provision of public goods which opens up new development paths for the economy (e.g. by founding new technical universities), public economic activities which could principally be run privately (such as forest management) but do not rival with industrial development, regulation of markets e.g. by liability rules, the introduction of social insurance and anti-market regulations such as price controls. At a closer look the bulk of public activities at all levels of government addressed public goods or club goods and can be interpreted as a remedy of market failure. ${ }^{20}$ As Pierenkämper and Tilly (2004) maintain, local governments which absorbed most of fiscal revenues supplied a large part of the infrastructure and public services - water, policing, fire protection, transportation facilities etc., 'upon which daily life and indeed the very functioning of the economy itself depended' (ibid., 143). Likewise, the provision of vocational schools, technical schools or universities is complementary to markets, which is why these public activities defy a categorization as 'market intervention'. Adapting the supply of public goods to the requirements of economic development spurs the ongoing capitalist development, rather than establishing comprehensive state control, as the ambitious Hegel-versus-Smith-debate prompts. ${ }^{21}$

\section{Liberal economic policy without democracy}

Undoubtedly, a special form of capitalism developed in Imperial Germany, characterized by a high responsiveness of the government to the requirements of private investment and, at least in comparison with other countries, also to social needs. But, the liberal character of economic policy did not undergo fundamental revision. It was assisted by the highly-developed rule of law which protected economic freedom as well as the independence of public administration. German legal scholars developed operational criteria for legislation and administration in order to contain state authority, among them the 'principle of proportionality' and the 'prohibition of excessiveness' (Schmidt-Aßmann, 1987). Admittedly, the rule of law was not a safeguard for competition in all cases. The Supreme Court judged price cartels as legal because they resulted from the freedom of transaction. In the

\footnotetext{
${ }^{18}$ This term has been coined by Wehler (2008: 663); for a detailed criticism see Hentschel (1978).

${ }^{19}$ For instance, the historian Wehler (2008: 662-667) rejects Smithian economic policy which he misperceives as pure ideology, considering public activities necessary; however, when public activities were initiated by conservative or liberal politicians, which was the case in the Bismarckian period of Imperial Germany, he assumes dishonest intentions.

${ }^{20}$ See Grimmer-Solem (2003) who demonstrates that the allegedly interventionist approach of the German Historical School is not so different from public tasks which present-day textbooks of economics attribute to government.

${ }^{21}$ For an overview of German economists' theorizing, see Priddat (1998).
} 
Weimar Republic, ordoliberal economists such as Böhm and Eucken took issue with this decision and developed the idea of an institutional framework for competition to be guaranteed by legislation and courts. $^{22}$

In order to assess one prediction of the approach by Acemoglu and Robinson (2012) one can ask by counterfactual reasoning whether a fully-fledged democracy would have given further strength to freemarket order institutions, or even removed its deficiencies (see above). Arguably, it would not have. Capitalist development at that time fueled class conflict between industrial workers and capitalists. Due to freedom of association - only interrupted in the 1880 s by the anti-socialist laws under Bismarck's chancellorship - and universal male suffrage, class conflict entered parliament at the federal state level, though not in Prussia which kept the class-voting system. In 1903 the socialist party (SPD), still orientating itself to Marxist ideology, and the Catholic Center, which, albeit for other reasons, rejected capitalism as well, obtained the majority in parliament. ${ }^{23}$ Ideologies matter. If parliament had elected the chancellor, anti-liberal parties could have taken control of economic institutions as they did after WWI. It is doubtful whether a parliamentary majority would have continued liberal economic policy if it were under its exclusive control. Illustrative is the refusal of the Prussian government to accept income taxes at the federal state level, which would have required a change of the constitution. When the conservative-liberal majority in Prussia had introduced a mildly progressive income tax at a prior point in time, it was wary to introduce income taxes at the federal level where socialists held a strong position and could attempt to increase the rate of progression (Spoerer, 2004: 116). It would likely have fulfilled the long-standing demand of the Communist Manifesto to introduce a sharply progressive tax rate on income.

In the same vein, one can ask whether elements of non-liberal economic policy such as the introduction of agricultural tariffs by Bismarck in 1878 is rightly attributed to the influence of large landowners (Junkers) in Eastern Germany and would have been avoided by a purely democratic order. Doubts are warranted. Protectionism in the agricultural sector responded to structural change (namely due to imports of agricultural goods from Russia) which brought about competitive pressure in the sector. But in contrast to Britain, land property in Germany (as in France and in Italy) was not monopolized by a tiny class of land-owners (Grant, 2005); rather, 'hundred thousands of middle-class producers represented fertile soil for protectionist movements' (Pierenkämper and Tilly, 2004: 152); these producers had their representation in parliament (mainly by the German Conservative Party). Hence, agricultural policy resembled much more group-interest policies of modern democracies rather than authoritarian imposition of policy against the interest of the mass population ${ }^{24}$; indeed, it was kept during the Weimar Republic. The turn toward higher tariffs in the agricultural sector is owed to gradual democratization in Imperial Germany rather than to its democratic shortcomings: in 1878, 204 members of parliament (out of 397) signed a declaration in favor of a reform in trade policy which gave rise to Bismarck's new tariff policy. ${ }^{25}$ It transpired that democracy and liberal economic policy could conflict with each other, even before the political change in 1919 gave effect to full democracy.

To conclude so far: incomplete parliamentarianism proved to be a practical interim solution from the viewpoint of capitalist order and the ascendant business class. Its main achievement was the formation of a stable institutional framework for long-term private investment. Imperial Germany was far away from a "constitutional crisis" as Hewitson claims (Hewitson, 2001). The liberal economic order was protected against anti-capitalist parties in parliament and benefitted from the dispersion of political power among the states. Therefore, class conflicts between well-organized workers and capitalists could not fundamentally challenge the capitalist order. At the same time, political participation was sufficient to control the course of policy. Hence, the lack of full parliamentarianism is better interpreted as a rational choice rather than the persistence of a pre-capitalist order, all the more

\footnotetext{
${ }^{22}$ See Böhm (1933) and Eucken (2004).

${ }^{23}$ In the Weimar republic, they formed the so-called Weimar coalition.

${ }^{24}$ See also Torp (2009).

${ }^{25}$ See Cambridge History Online (2008: 58).
} 
since amendments of the constitution were possible but refused by conservative and liberal parties in parliament. ${ }^{26}$ After parliament declined proposals of the government to criminalize labor strikes and refused to resume Bismarck's anti-socialist policy in 1894 and 1899, the government reviewed its onesided support of capitalists. Now the integration of the workers into society, accepting their political representation, was on the political agenda. Government played a more neutral role of an 'arbiter' (namely in the mass strike of 1905 in the Ruhr Area). ${ }^{27}$ This informal change of the role of the political order formed a compromise between political demands of the workers and the liberal uppermiddle class. ${ }^{28}$ It also stabilized the liberal economic order until 1914.

A final point concerning the economic order before WWI relates to foreign trade policy which is most critical for the argument that democracy and capitalism necessitate each other. In contrast to Friedrich List's recommendation of protection for infant industries, practical policy in Prussia and Imperial Germany never pursued such policies throughout the 19th century until WWI. The Tariff Union (Zollverein), which comprised most of the German middle states and Prussia, also continued this low tariff policy, interrupted in the 1850s by the crisis of the Zollverein (some South German states which requested higher tariffs pondered a political union with Austria instead of Prussia; for political reasons Prussia decided to make concessions in this realm). But after the CobdenChevalier-Treaty between Britain and France, Prussia resumed its free-trade policy and concluded a trade agreement with France in 1862. This period lasted until 1879 so that 'Germany has virtually become a free trade country' (Bairoch, 1989: 41) with an average duty of 3\% (Dedinger, 2006: 233). A detailed analysis of Bismarck's tariff policy and its succession by later governments shows that the increase of tariffs was not 'a fatal turning point ...in the history of modern Germany' (Kindleberger, 1989: 478, quoted by Dedinger, 2006: 233). Technically advanced products remained nearly unprotected while the interest in fiscal revenues dominated; protectionism concerned only some industries (rye and wheat growing, cotton spinning, pig iron smelting, rail making) which made up 2-3\% of exports and 7\% of all imports (Dedinger, 2006: 239). This level of protection was in line with France, moderately higher than the British level, but substantially lower than protectionism in the United States. Remarkably, foreign trade policy developed in contrast to the political order. The non-democratic state of Prussia, which even lacked a constitution until 1848, committed itself to a free trade policy, while the increase of tariffs tended to coincide with the gradual increase of power of the parliament (Reichstag). This tendency challenges the view that 'open access' (North et al., 2009) in politics accords with open access in the economy or vice versa ('inclusiveness' in terms of Acemoglu and Robinson, 2012).

Notwithstanding these protectionist tendencies before 1914, liberal economists such as Wilhelm Röpke approved of the international economic order in retrospect as workable (Röpke, 1942, 1945). The most favored nation clause removed preferential tariffs and formed an international order from below, i.e. on bilateral treaties. The gold standard contributed to the monetary stability of the international order which had its financial center in London. The international order defied the rivalries of the leading powers, but also embedded the national economic orders. Consequently, interventionism and cartelization could not proliferate or change the domestic economic order in Germany. The international order thus buttressed the domestic liberal economic order.

\footnotetext{
${ }^{26}$ This interpretation accords with Eley and Blackbourn's position but diverges from its Marxist theoretical framework (Blackbourn and Eley, 1980).

${ }^{27}$ See Kroll (2013: 26-27) and Wehler (2008: 1088).

${ }^{28}$ Other Western democracies, such as Britain, the Netherlands or Sweden, established stable liberal orders as well but found an alternative way. Full parliamentary control of the government (which elected the prime minister) could not challenge the liberal economic order since constraints of universal suffrage excluded larger parts of the working class; in Britain, for instance, the working class lacked representation in the House of Commons nearly throughout the entire 19th century. In France, which was an exceptional case of universal male suffrage and full democracy, the class conflict was less pronounced due to the delay of industrial development. Therefore, democracy was unlikely to challenge the capitalist order which was largely based on middle class petits entrepreneurs and small land-owners.
} 


\section{The political and economic order in the Weimar Republic}

\section{The transformation of the political and economic constitution}

The end of the Great War changed the political order in Europe fundamentally. A push toward full democracy occurred in many European countries and included non-combatant countries which removed their old regimes. In the course of the 1920s and 1930s, however, nearly all newly introduced democracies collapsed and gave way to authoritarian regimes; Italy in 1922, Lithuania, Poland and Portugal in 1926; Yugoslavia in 1929; Germany and Austria in 1933; Latvia, Estonia and Bulgaria in 1934; Spain and Greece in 1936 and Romania in $1938 .{ }^{29}$ France only narrowly escaped authoritarianism. However, the case of Germany (and Austria with a slight modification) is exceptional insofar as no other country turning to authoritarianism had a similarly long-lasting tradition concerning the rule of law and political representation.

In Germany the change of the political order in 1919 removed imperial rule and the monarchies in the states. Parliament now elected the chancellor while the president was elected by a popular vote. The federal state had been formally kept but underwent a substantial change: The position of the states (now: Länder) became weakened, and parliament could overrule a veto by the Federal Council (Bundesrat) on legislation. Civil rights were now protected centrally by the Weimar Constitution rather than by constitutions of the states; the Weimar Constitution also included an emergency clause which made the abrogation of civil rights possible. ${ }^{30}$ The centralization of the state emerged in wartime and was certainly a suitable measure to meet the new fiscal requirements of the state in peacetime, not least the payment of reparations. A side effect was that civil rights became more vulnerable when radical parties strove for exclusive power. Nevertheless, in the period from 1919 to 1923 the new democratic order was able to fend off several attacks from left-wing and right-wing radicals and ushered in the 'stabilization period' of the Weimar Republic from 1923 to 1929. However, the centralization of the political order turned out to be toxic when authoritarian presidential cabinets replaced ordinarily elected cabinets after 1930 (starting with Chancellor Brüning).

Regulatory and tax competences became centralized after the founding of the Weimar Republic. The states lost their fiscal autonomy as a result of the fiscal reform launched by the Minister of Finance, Matthias Erzberger. In consequence, regulatory competition as well as tax competition disappeared. The market economy in Germany suffered without a market preserving federal order which had been one of the political pillars that dominated the pre-war order. Now every change of economic policy had to be initiated by the central government and could not start from below in the states. Overtaxation of firms could not be remedied at the local or subnational level; nor could municipalities or states attract firms or wealthy tax-payers by lowering corporate or income taxes. This centralization of economic policy met the requirements of fiscal post-war necessities, among them pensions for war victims and reparation payments; but it was one contribution to the decline of the liberal pre-war economic order. As a result, the ratio of state expenditure to GDP rose from $15 \%$ in 1913 to $26 \%$ by the end of the 1920 s and soared to $35 \%$ during the Depression, which illustrates the changed role of the state in the new economic order (Borchardt, 1982: 196). At the same time, economic growth came to a halt; apart from 1926, industrial production never reached the level it had attained in 1913.

Overall, democratization combined with the centralization of the state paved the way toward a politicization of the economic order. The organized working class gained considerable influence. This shift of political power in favor of labor at the expense of capital occurred in many European countries (Raphael, 2011: 174). It gave rise to a new type of capitalism which modified and sometimes fundamentally revised capitalist institutions such as property rights, the freedom of contract and the role of the state in the economy. The redistribution of income and market interventionism began to change economic institutions significantly.

\footnotetext{
${ }^{29}$ For a comprehensive study see Barth (2016).

${ }^{30}$ Hitler made use of this emergency clause in 1933.
} 
Such change of capitalist institutions challenges Acemoglu and Robinson's approach resting on the correspondence of capitalist institutions and democracy. Since, in principle, both orders are inclusive, one would expect that democracy leaves capitalist institutions intact. Economic history after WWI highlights the hidden epistemic presumption of this approach. Even the empirical evidence that capitalist institutions are the most useful for general prosperity would have to assert itself in the competition of votes. As soon as parties with anti-capitalist platforms succeed, democracy could weaken and even transform capitalist institutions. Such development existed shortly after the Great War in Germany. In the wake of communist revolts in November of 1919 and the short-lived establishments of 'Soviet governments' at the local level, unions urged capitalists to accept the eight-hour work day by offering to waive the nationalization of heavy industries ('Stinnes-Legien-Agreement'). Later on, the unions preferred a conception of 'economic democracy'. ${ }^{31}$ In retrospect it came close to the co-determination after WWII, forming cooperative industrial relations in West-Germany, but at the time it was thought of as a first step to take full unionist control over industry.

Although the SPD did not intend to establish a planned economic order and markets prevailed as the dominant instrument for economic coordination, capitalist institutions became attenuated at several levels. The Weimar Constitution modified the guarantee of property rights which had to be aligned with a vaguely defined principle of public welfare. The nationalization of land and property became possible in principle, albeit in combination with compensation of the private owners (Art. 153, 155 and 156 of the Weimar Constitution). Wages were negotiated by collective bargaining between unions and employer associations. If they could not find a compromise, the Ministry of Labor could impose a compulsory wage settlement. This procedure provided incentives for the unions to take control of this ministry. Company agreements which could have taken consideration of the profitability of firms were only a secondary priority for the unions. Against this background, entrepreneurs and trade associations complained about the 'Union State' which seized the power to set wages.

Cartels and monopolies undermined the market economy as well. This development gained momentum as a result of the war economy when the state depended on heavy industry. This support continued in peacetime. But apart from this path-dependence, cartels can also be interpreted as the reaction of firms to control prices in response to their diminishing influence on wages, given the prewar period as a reference. The state, in turn, was more willing to give firms a relief in return for imposed wage settlements and therefore tolerated cartels. The cartelization of the economy was surely also an international phenomenon and even considered an indication of an efficient economy. ${ }^{32}$ This ideology in favor of cartels and large-scale monopolies spurred the attitude of economic policy. Ordoliberal economists such as Eucken or Böhm were the exception in their critique of cartels and dominant market players; they claimed that both would remove competition and free market prices as the key device for coordination (Böhm, 1933; Eucken, 2004). These systematic reflections of the new economic order questioned the close entanglement of the economy and the state, which rendered the market economy more and more ineffective.

\section{Intensifying crisis and dissolution of the Open Access Order}

Whether and to what extent the politicized economic order contributed to the economic crisis of the Weimar Republic and to its dissolution is a controversially discussed topic. The incorporation of the welfare state into the economic order, taken in isolation, can contribute to the legitimacy to capitalism and need not produce economic crises, as the economic history of West-Germany after WWII confirms. This, however, requires that the welfare state does not overtax the economy and stifle investment. But there is a strong indication that this scenario took place. ${ }^{33}$ The rate of investment fell from 16\% of GDP in 1913 to 13\% in 1925 and reached a far lower level in 1929 (7\%); the rate of consumption, by contrast, reached higher levels than before WWI ( $80 \%$ in 1929 compared to $73 \%$ in 1913;

\footnotetext{
${ }^{31}$ See Naphtali (1966); for a modern restatement of this conception see Dahl (1985).

${ }^{32}$ See above; see also Reckendrees (2003).

${ }^{33}$ For an overview see Balderston (2002).
} 
Knortz, 2010: 20). Borchardt claims that the period of stabilization from 1923 to 1929 prepared the ground for the deep crisis after 1930 and made for a 'crisis before the crisis'. According to Borchardt, the significant bargaining power of the unions squeezed profits before the outbreak of the Great Depression (Borchardt, 1979). This provoked objections from 'Keynesian' economic historians such as Holtfrerich and gave way to a fundamental controversy about the adequacy of a supply-side-interpretation. ${ }^{34}$ Ritschl (2002) supports Borchardt's argument of rising unit-labor costs as a result of compulsory wage settlements, which is in line with Keynes's judgment of the competitiveness of the German economy (ibid., 86-90). While distributional conflicts and excessive wage claims are a feature of any democracy, they fueled political conflicts and prompted entrepreneurs to distance themselves from democracy, particularly at the end of the 1920s. Unlike the pre-war period where German entrepreneurs invested globally on a large scale, such relocation of production was hardly possible in the inter-war period. Because production facilities abroad had been confiscated by the Allied Powers, foreign direct investment was risky, if not impossible. This strengthened the incentive of entrepreneurs to protect the domestic market and improve the investment climate at home by influencing the course of economic policy.

Because of the unsatisfactory results of their lobbying, entrepreneurs ceased to consider democracy as a suitable political framework for capitalism. The end of the last elected cabinet under Chancellor Hermann Müller (Socialdemocratic Party) marked the end of compromises between the increasingly left-wing SPD and business interests represented by the DVP. During the Great Depression entrepreneurs looked for an opportunity to revise the former redistribution and establish political arrangements which could exclude this scenario for the period following the crisis. In practice, this meant turning away from democracy. This concern was paralleled by conservative elite groups including Chancellor Brüning, who considered the Great Depression as a chance to rebalance the power between labor and capital.

Distributional conflicts intensified as a result of economic stagnation, which distinguishes the post WWI-period fundamentally from the post WWII-epoch. Because the Weimar welfare state lacked financial resources, it remained rudimentary and to some extent a mere promise, which is why one of the three pillars of the Weimar state - i.e. democracy, the rule of law, and welfarism - was fragile. Support for groups, e.g. for nonviable small farms in the oversized agricultural sector, turned into a zero sum game. ${ }^{35}$ In order to finance subsidies for the agricultural sector which suffered hardship from low prices, salaries for civil servants were cut by $25 \%$. This dramatic scarcity of resources also explains why the termination of reparation payments gained key priority for the government, namely at the height of the crisis in 1932. Besides, the intensity of distributional conflicts, particularly after 1929, suggests that the widely discussed question whether the reparation burden of the Young Plan between 2 and 3\% of the GDP - was bearable for 'Germany' misconstrues the problem. Rather, it needs to be re-stated from the viewpoint of political economy: Could any democratically elected government reduce real income of citizens or groups through higher taxes, lower pensions, lower subsidies or lower unemployment payments without being voted out of office? Obviously, any ruling coalition had a strong incentive to gain a budgetary margin for moderating the crisis. But a similar logic applies to the Allied Powers as well. Their government had likewise strong incentives to avoid higher taxes for their own voters in order to pay their war debts to American banks; in view of political competition it was far easier to foster the illusion that war debts could entirely be shifted to Germany.

Economic stagnation (apart from a 2-year period in the mid-1920s) and especially the Great Depression proved to be a severe impediment for structural change. Particularly the agricultural sector which employed nearly $30 \%$ of the workforce required reduction in terms of absolute employment figures. In the late 19th century, which had witnessed steady growth rates, the agricultural sector could shrink relatively with even higher absolute employment figures. High growth rates of the

\footnotetext{
${ }^{34}$ See Borchardt (1979), Holtfrerich (1984), Spoerer (1994) and Ritschl (2002).

${ }^{35}$ State aid for agriculture increased from RM 500 million (RM) in 1927 to RM 2 billion in the crisis year of 1932; it was estimated that grain tariffs burdens consumers in the amount of 3.7\% of the net national product in 1932 (Knortz, 2010).
} 
West-German economy after WWII likewise facilitated such 'creative destruction' without social disruption. In the Weimar Republic, by contrast, industry was unable to absorb displaced peasants. Therefore government protected the agricultural sector; before the deep crisis, the government doubled tariffs for wheat in order to protect the income of farmers at the expense of other citizens (Kindleberger, 1989: 168). ${ }^{36}$ At the height of the crisis voting behavior in the rural area shifted dramatically away from traditional conservative parties toward the National Socialists.

Theoretical approaches which argue that inclusive institutions in politics and the economy are mutually supportive must acknowledge that dramatic structural change does not only affect elite groups, as Acemoglu and Robinson (2012) argue, but also larger groups in society. This was the case at the end of the Weimar State. In the absence of economic growth and the demand for fundamental structural change in the economy, democracy lacked resources to moderate and cushion the social consequences of unemployment. 'Inclusiveness of institutions' thus becomes an empty phrase. Today this type of scenario is rarely a part of a theoretical consideration about the possibility of a selfstabilizing relationship between democracy and capitalism.

Contemporaries such as Eucken or Böhm, but also American analysts who assessed the German capacity to pay reparations, observed that firms became increasingly risk-averse and lacked entrepreneurial spirit. Eucken stressed that this behavior was in contrast to the 19th century and resulted from the new democratic order and its political risk (Eucken, 1932: 14). ${ }^{37}$ Commenting on the course of economic policy in the Weimar Republic, he complained about the 'nervous restlessness' and the lacking 'atmosphere of trust' (Eucken, 2004: 288). James supports this view when he argues that uncertainty about the course of economic policy frustrated investment plans of firms and was a crucial factor for the economic crisis throughout the Weimar State (James, 1988: 84). In contrast to the period before the war, entrepreneurs had to speculate on future economic policy in order to assess the profitability of their plans.

\section{The change of the international economic order}

The inter-war period saw a new type of interventionism unknown before the war. A dramatic change of the international economic order corresponded to the revision of domestic economic policy. The breakdown of the international order before WWI, which was, all in all, liberal, and the failure of its restoration was alarming for German liberal economists such as Eucken and Röpke. As for domestic economic policy they held the new political order responsible for this failure. In retrospect they considered the pre-war international order as a driving force for capitalist dynamism:

It was no coincidence that the century of uninterrupted existence of this international order of states was at the same time the century of the greatest expansion of capitalism. The stability and security of foreign relations created the basis of trust for international capital movements and made it possible to create a network of long-term trade agreements ... which greatly enhanced the growth of capitalism, especially in countries such as England and Germany (Eucken, 1932: 17).

Two developments shaped the new international economic order. On the one hand, the emergence of new states disrupted trade relations that grew as a result of the Parisian Suburb Contracts. Particularly, the division of the Habsburg Empire distorted traditional trade relations. This alone increased the negotiation and coordination efforts of international trade agreements. On the other hand, an 'economic nationalism' (Röpke, 1942) shaped international trade policy. International trade was not perceived as cross-border trade between economic agents, but as trade between nations, which is fundamentally alien to the liberal view (Röpke, 1945: 83).

Foreign trade policy became a policy field in which national interest policy and the service of group interests coincided, often with group interests prevailing. Czechoslovakia, for example, established a

\footnotetext{
${ }^{36}$ France also raised tariffs before resorting to quotas (ibid.)

${ }^{37}$ For a more careful assessment of Eucken's critical stance to democracy see Nientied and Köhler (2016).
} 
high-tariff regime vis-à-vis Germany in order to protect Bohemia's quite competitive industry, increasing prices for industrial products (cars, electrical appliances) in its own country by up to $100 \%$ (Krpec, 2015). A coalition of entrepreneurs and nationalist politicians enforced a customs policy here which constrained real incomes in the country, accepting through economic disintegration, in spite of geographic proximity to the much larger market in Germany, the non-realization of specialization advantages. Disintegration after the war caused a serious problem mainly because new production methods, among them the newly tried flow production, were increasingly based on economies of scale and therefore required integrated markets (Röpke, 1942: 63). Hence, global economic disintegration implied a significant step backward with both limited productivity and limited economic growth.

The closure of markets favored monopolies and cartels in the domestic economy, which were always vulnerable without external protection. Now interventionism and protectionism reinforced each other. Against this background the question of how to keep group interests at bay through constitutional rules that protect competition became the dominant theme in ordoliberal thinking (Brunnermeier et al., 2016: 59-62).

There was no lack of attempts to restore the liberal pre-war order. On the contrary, the inter-war period witnessed international economic conferences which were unknown in the period of bilateralism before the war. In spite of efforts to reduce tariffs, the World Economic Conference in 1927 in Geneva recognized that states were unwilling to accept a return to low tariffs. The General Assembly of the League of Nations in 1929 moved from attempts at reduction to a preservation of the status quo. In 1930, Norway, Sweden, Belgium and the Netherlands signed an agreement to give notice to each other if one country chose to raise tariffs unilaterally (Kindleberger, 1989: 169). Multilateral tariff cuts (with exceptions to be negotiated) or maximum tariffs were beyond imagination.

These poor results help to explain widespread reservations against the capacity of democracy to solve economic problems at the time. Referring to the reparation problem in particular and 'economic nationalism' in general, Eucken stressed that it was political competition which constrained far-sighted action.

Global economic disintegration not only limited the growth potential of the major trading nations. At the same time, it decisively aggravated the international debt problem as a consequence of the WWI because, unlike after World War II (WWII), the belligerent countries could not 'outgrow' their war debts. From the very beginning, the Weimar state was burdened by the circumstance of having to pay off its own war costs as well as the imposed reparations. To simplify matters, its own war costs were settled by the abandonment of the gold standard at the beginning of the war and accelerating inflation, finally reaching its dramatic peak in the hyperinflation of 1923 and culminating in the complete temporary collapse of the currency. The attempt of the victors to additionally impose the foreign war costs on defeated Germany and, despite obvious insolvency, to hold on to it even during a massive depression, proved to be wishful thinking. In the beginning, the total sum amounted to more than fourfold of total GDP in 1913; according to the Young-Plan in 1929 it was substantially reduced but still made up 2.5 to $3 \%$ of GDP (to be paid in annual rates for the next 55 years). In any case, the receivables had to be paid by foreign exchange surpluses and therefore required an active current account. The protectionism of the interwar period, however, made this extremely difficult to realize, which is why deflationary policy was considered the last resort to undercut tariff barriers, as Borchardt argues in defense of Chancellor Brüning's policy (Borchardt, 1982). ${ }^{38}$ With the introduction of foreign exchange controls in 1931, the departure from the basic principles of the free movement of goods and capital in favor of governmental intervention came to its temporary end. Although the European democracies had abstractly understood that free trade was desirable, as was repeatedly expressed in the League of Nations, no practical results followed (Kindleberger, 1989: 167; Röpke, 1945: 26). Instead

\footnotetext{
${ }^{38} \mathrm{~A}$ detailed discussion is beyond the scope of this paper. While Borchardt's defense of Brüning's policy appears to be reasonable, a broader discussion must consider that Brüning's agenda included the abandonment of democracy; this priority excluded measures to mitigate the crisis, if only by symbolic measures; see also Peukert (2014).
} 
of viewing the reparation problem in isolation, its combination with disrupted trade relations gives the more realistic picture of an unsolvable economic problem for the German economy. Both, however, emanated from domestic policies and the requirements of politicians who sought to survive political competition. Neither free trade agreements nor relief from reparations for Germany would have been acceptable to their electorates. Keynes was largely alone with his view that the recovery of the world economy required economic recovery in Germany, and only in this circumstance did the British economy have a chance of overcoming its equally persistent crisis (Keynes, 2002). His cosmopolitan view was alien to democratic conformity and simply disregarded. Any critical examination of the allegedly anti-democratic attitude of the German ordoliberals must take note of this historical background.

In addition to the existence of trade barriers as such, the short-sightedness and ephemeral nature of trade policy mattered. Röpke made its unpredictability for exporting firms responsible for economic disintegration, which is supported by Kindleberger (1989) and Röpke (1942: 50). The international order prior to WWI, despite its shortcomings, was judged as a good, viable order, even for a long time after WWII. For that reason, ordoliberals including the Economics Minister, Ludwig Erhard, were wary about the European Economic Community, which they suspected of leading to the return of pre-war protectionism at a regional level (Petersen and Wohlgemuth, 2009).

By comparison, it is striking that the mixed economy after WWII maintained many elements of the economic order of the inter-war period, namely the gradual expansion of state expenditures including the welfare state, while countries were plagued by the cost of the war as well. The key difference was the successful establishment of a stable institutional framework based on rules, both at the national and international levels. The restoration of an international economic order did not eliminate the 'anti-capitalist elements' in any democratic economic policy. However, to the extent that its disincentives could not be 'remedied' by protectionist policies, a control mechanism was installed. This seems to have been significant for the successful 'double balance' after the WWII, something that a general theoretical framework should take into account.

\section{Conclusion}

The economic consequences of the democratization process after WWI are ambivalent. On the one hand, the Weimar State resisted the attempt to establish a planned economy on the Soviet model; this failed to be an attractive political bargain for the middle class in particular. On the other hand, the introduction of democracy based on universal suffrage coincided with the weakening of capitalist institutions even though prices remained the key device for coordination.

This challenges recent approaches which too straightforwardly claim the correspondence of democracy and the market economy by mutually reinforcing each other. We have concentrated on the change of economic institutions of the Weimar State, but other European countries underwent similar developments. Due to the lost war, however, crisis factors in Germany intensified and entangled themselves in an ultimately fatal way, leading to the dramatic climax of the crisis in 1932. At that time, democracy on a broad front lost its consent both in society and within elite groups. Traditional liberal parties (DDP and DVP) which shaped political and economic development since the early 1860s nearly disappeared from political life. But economic institutions deteriorated as well and weakened the mechanism of coordination through prices. It was too obvious that the inability of Germany and other European states to restore a stable institutional framework for the economy had something to do with the intrinsic laws of democratic competition for votes. Usually, the lack of democratic sentiment is blamed for the failure of democracy in the Weimar Republic. From our point of view, this explanation falls short because the support for democracy, particularly when newly introduced, depends on its performance. ${ }^{39}$ The crisis years of the Weimar Republic revealed a fundamental

\footnotetext{
${ }^{39}$ See also Anderson (2009). Besides, it is doubtful whether the democratic attitude among civil servants or the people after the WWII was more pronounced, as we know from recent historical investigations on the National Socialist heritage in the ministries of West-Germany. Belief in democracy is much more the result of successful performance of democracy.
} 
problem of any democracy quite drastically, namely the restoration of a functioning liberal order in the event of massive opposition from voter groups which have to bear the cost of structural adjustment. The national and the international dimension of this problem were overlapping.

No virtuous cycle of democracy and the market economy emerged as North et al. (2009) and Acemoglu and Robinson (2012) would have predicted. The downward trend already originated from democracy and did not start with its previous elimination. The international aspect of this development was particularly sobering. While it may be true that democracies do not make war against each other, they were incapable of providing an international institutional framework for prosperity in peacetime. By contrast, the 'half and three quarter democracies' (Tooze) of the prewar period secured such a framework at home and internationally, apart from their inability to secure peace. ${ }^{40}$

The limited economic problem-solving capacities of democracy became a formative experience for ordoliberal economists such as Eucken and Böhm who were worried about the political feasibility of economic reason in democracy. It turned out that stability, predictability and investment-friendly taxes and regulation were hard to realize in democracy, notwithstanding the justifiability of social policy objectives. The search for a solution of this trade-off would become a dominant topic of German economic policy. To conclude, the inter-war period offers a lesson that inclusiveness of institutions is a necessary but not a sufficient condition for self-stabilization of capitalism and democracy.

Acknowledgements. For detailed comments of an earlier version I wish to thank three anonymous referees.

\section{References}

Acemoglu, D. and J. Robinson (2012), Why Nations Fail. The Origins of Power, Prosperity, and Poverty, New York: Crown. Acemoglu, D., S. Johnson and J. Robinson (2004), 'Institutions as the Fundamental Cause of Economic Growth', NBER Working Paper 10481, Cambridge, MA.

Ambrosius, G. (2005), Regulativer Wettbewerb und koordinative Standardisierung zwischen Staaten. Theoretische Annahmen und historische Beispiele, Stuttgart: Franz Steiner Verlag.

Anderson, M. L. (2009), Lehrjahre der Demokratie. Wahlen und politische Kultur im Kaiserreich, Berlin: Franz Steiner Verlag. Balderston, T. (2002), Economics and Politics in the Weimar Republic, Cambridge: Cambridge University Press.

Bairoch, P. (1989), 'European trade policy, 1815-1914', in P. Mathias and S. Pollard (eds.), The Cambridge Economic History of Europe, VIII, Cambridge: Cambridge University Press, pp. 1-160.

Barth, B. (2016), Europa nach dem Großen Krieg. Die Krise der Demokratie in der Zwischenkriegszeit 1918-1938, Frankfurt: Campus Verlag.

Blackbourn, D. and G. Eley (1980), Mythen deutscher Geschichtsschreibung. Die gescheiterte bürgerliche Revolution von 1848, Frankfurt a. M.: Ullstein Taschenbuch.

Boch, R. (2004), Staat und Wirtschaft im 19. Jahrhundert, München: Oldenbourg.

Böhm, F. (1933), Wettbewerb und Monopolkampf. Eine Untersuchung zur Frage des Wirtschaftlichen Kampfrechts und der Rechtlichen Struktur der Geltenden Wirtschaftsordnung, Berlin: Carl Heymanns. Reprint: Köln: Carl Heymanns (1964).

Böhm, F. (1966), 'Privatrechtsgesellschaft und Marktwirtschaft', ORDO, 17: 75-151.

Borchardt, K. (1979), 'Zwangslagen und Handlungsspielräume in der großen Weltwirtschaftskrise der frühen dreißiger Jahre: Zur Revision des überlieferten Geschichtsbildes', in Jahrbuch der Bayerischen Akademie der Wissenschaften, München: C.H. Beck, pp. 87-132.

Borchardt, K. (1982), Wachstum, Krisen, Handlungsspielräume der Wirtschaftspolitik. Studien zur Wirtschaftsgeschichte des 19. und 20. Jahrhunderts, Göttingen: Vandenhoek \& Ruprecht.

Bösch, F. (2009), 'Grenzen des “Obrigkeitsstaates”. Medien, Politik und Skandale im Kaiserreich', in S. O. Müller and C. Torp (eds.), Das Kaiserreich in der Kontroverse, Göttingen: Vandenhoek \& Ruprecht, pp. 136-153.

Brunnermeier, M., H. James and J.-P. Landau (2016), The Euro and The Battle of Ideas, Princeton, Oxford: Princeton University Press.

Buchanan, J. M. and R. D. Congleton (1998), Politics by Principle, Not Interest, Cambridge: Cambridge University Press.

Congleton, R. (2011), Perfecting Parliament. Constitutional Reform, Liberalism and the Rise of Western Democracy, Cambridge: Cambridge University Press.

Dahl, R. (1985), A Preface to Economic Democracy, Berkeley: University of California Press.

\footnotetext{
${ }^{40}$ See Tooze (2015)
} 
Dedinger, B. (2006), 'From Virtual Free-Trade to Virtual Protectionism: Or, Did Protectionism Have Any Part in Germany's Rise to Commercial Power 1850-1913?', in J.-P. Dormois and P. Lains (eds.), Classical Trade Protectionism 1815-1914, Abington: Routledge, pp. 219-241.

de Haan, J. and J.-E. Sturm (2003), 'Does More Democracy Lead to Greater Economic Freedom? New Evidence for Developing Countries', European Journal of Political Economy, 19(3): 547-563.

Eucken, W. (1932), 'Staatliche Strukturwandlungen und die Krisis des Kapitalismus', Weltwirtschaftliches Archiv, 36: 297321. Reprint in ORDO (1997) 48: 5-24.

Eucken, W. (2004), Grundsätze der Wirtschaftspolitik, Tübingen: Mohr Siebeck.

Friedman, M. (1962), Capitalism and Freedom, Chicago, IL: Chicago University Press.

Grant, O. (2005), Migration and Inequality in Germany 1870-1913, Oxford: Oxford University Press.

Grimmer-Solem, E. (2003), The Rise of Historical Economics and Social Reform in Germany 1864-1894, Oxford: Clarendon Press.

Grimmer-Solem, E., A. Reckendrees, G. Wegner and J. Zweynert (2019), 'Das Konzept der "Limited and Open Access Orders” und die politisch-ökonomische Entwicklung Deutschlands zwischen 1815 und 1933', in G. Schulz (ed.), Ordnung und Chaos. Trends und Brüche in der Sozialgeschichte, Stuttgart: Franz Steiner Verlag, pp. 153-168.

Hallerberg, M. (1996), 'Tax Competition in Wilhelmine Germany and its Implications for the European Union', World Politics, 48(3): 324-357.

Hayek, F. (2005), Die Verfassung der Freiheit, Tübingen (Mohr).

Hayek, F. A. V. (1991), Die Verfassung der Freiheit, 3rd ed., Tübingen: Mohr.

Hentschel, V. (1978), Wirtschaft und Wirtschaftspolitik im wilhelminischen Deutschland. Organisierter Kapitalismus und Interventionsstaat, Stuttgart: Klett-Cotta.

Hewitson, M. (2001), 'The Kaiserreich in Question: Constitutional Crisis in Germany Before the First World War', The Journal of Modern History, 73(4): 725-780.

Holtfrerich, C.-L. (1984), 'Zu hohe Löhne in der Weimarer Republik? Bemerkungen zur Borchardt-These', Geschichte und Gesellschaft: Zeitschrift für historische Sozialwissenschaft, 10(1): 122-141.

James, H. (1988), Deutschland in der Weltwirtschaftskrise 1924-1936, Stuttgart: DVA.

Keynes, J. M. (2002), The Economic Consequences of the Peace, New York: Penguin.

Kindleberger, C. (1989), 'Commercial Policy Between the Wars', in P. Mathias and S. Pollard (eds.), The Cambridge Economic History of Europe from the Decline of the Roman Empire (The Cambridge Economic History of Europe), Cambridge: Cambridge University Press, pp. 161-196.

Knortz, H. (2010), Wirtschaftsgeschichte der Weimarer Republik, Göttingen: Vandenhoeck \& Ruprecht.

Kroll, F.-L. (2013), Geburt der Moderne. Politik, Gesellschaft und Kultur vor dem Ersten Weltkrieg, Berlin-Brandenburg: be.bra.

Krpec, O. (2015), 'Czechoslovakian Trade Policy after World War I (1918-1927): Nationalism and Capitalism', Working paper presented at the Geopolitical Economy of the 21st Century World, GERG Conference, Winipeg, Canada, http://gergconference.ca/wp-content/uploads/2015/09/Krpec-paper-Czechoslovak-Trade-Policy-in-1920s-2.pdf (last accessed 26 November 2019).

Lawson, R. A. and J. R. Clark (2010), 'Examining the Hayek-Friedman Hypothesis on Economic and Political Freedom', Journal of Economic Behavior \& Organization, 74(3): 230-239.

Naphtali, F. (1966), Wirtschaftsdemokratie - Ihr Wesen, Weg und Ziel, Frankfurt: Europäische Verlagsanstalt.

Nientiedt, D. and E. Köhler (2016), 'Liberalism and Democracy - A Comparative Reading of Eucken and Hayek', Cambridge Journal of Economics, 40(6): 1743-1760.

North, D. C., J. J. Wallis and B. R. Weingast (2009), Violence and Social Orders. A Conceptual Framework for Interpreting Recorded Human History, Cambridge: Cambridge University Press.

Olson, M. (1982), The Rise and Decline of Nations. Economic Growth, Stagflation and Social Rigidities, New Haven and London: Yale University Press.

Petersen, T. and M. Wohlgemuth (2009), 'Wilhelm Röpke und die Europäische Integration', in H. Rieter and J. Zweynert (eds.), 'Wort und Wirkung'. Wilhelm Röpkes Bedeutung für die Gegenwart, Marburg: Metropolis, pp. 165-200.

Peukert, D. J. K. (2014), Die Weimarer Republik. Krisenjahre der Klassischen Moderne, Frankfurt a.M.: Suhrkamp.

Pierenkämper, T. and R. Tilly (2004), The German Economy During the Nineteenth Century, New York and Oxford: Berghahn Books.

Prados De La Escosura, L. (2016), 'Economic Freedom in the Long Run: Evidence from OECD Countries (1850-2007)', Economic History Review, 69(2): 435-468.

Priddat, B. (1998), Produktive Kraft, sittliche Ordnung und geistige Macht. Denkstile der deutschen Nationalökonomie im 18. und 19, Jahrhundert, Marburg: Metropolis.

Raphael, L. (2011), Imperiale Gewalt und mobilisierte Nation. Europa 1914-1945, München: Beck.

Reckendrees, A. (2003), 'From Cartel Regulation to Monopolistic Control? The Founding of the German "Steel Trust" in 1926 and its Effect on Market Regulation', Business History, 45(3): 22-51. 
Ritschl, A. (2002), Deutschlands Krise und Konjunktur 1924-1934. Binnenkonjunktur, Auslandsverschuldung und Reparationsproblem zwischen Dawes-Plan und Transfersperre, Berlin: Akademie.

Röpke, W. (1942), International Economic Disintergration, London, Edinburgh and Glasgow: William Hodge and Company. Röpke, W. (1945), Internationale Ordnung, Zürich: Rentsch.

Schmidt-Aßmann, E. (1987), 'Der Rechtsstaat', in J. Isensee and P. Kirchhof (eds.), Handbuch des Staatsrechts der Bundesrepublik Deutschland, Vol. I, Heidelberg: Müller, pp. 987-1043.

Spoerer, M. (1994), 'German Net Investment and the Cumulative Real Wage Position, 1925-1929: on a Premature Burial of the Borchardt Debate', Historical Social Research, 19(4): 26-41.

Spoerer, M. (2004), Steuerlast, Steuerinzidenz und Steuerwettbewerb. Verteilungswirkungen der Besteuerung in Preußen und Würtemberg (1815-1913), Berlin: De Gruyter.

Stroup, M. (2008), 'Economic Freedom, Democracy, and the Quality of Life', World Development, 35(1): 52-66.

Sunde, U. (2006), 'Wirtschaftliche Entwicklung und Demokratie: Ist Demokratie ein Wohlstandsmotor oder ein Wohlstandsprodukt', IZA Discussion Paper No. 2244.

Tooze, A. (2015), Sintflut. Die Neuordnung der Welt 1916-1931, München: Siedler.

Torp, C. (2009), 'Erste Globalisierung und deutscher Protektionismus', in S. O. Müller and C. Torp (eds.), Das Kaiserreich in der Kontroverse, Göttingen: Vandenhoek \& Ruprecht, pp. 422-440.

Wehler, H.-U. (2008), Deutsche Gesellschaftsgeschichte Vol. III. Von der "Deutschen Doppelrevolution" bis zum Beginn des Ersten Weltkriegs 1849-1914, München: Beck.

Weingast, B. (1995),'The Economic Role of Political Institutions: Market Preserving Federalism and Economic Development', Journal of Law, Economics and Organisation, 7(1): 1-31.

Cite this article: Wegner G (2020). Reassessing the dependence of capitalism on democracy - the case of Imperial Germany and the Weimar Republic. Journal of Institutional Economics 16, 337-354. https://doi.org/10.1017/S1744137419000766 